Research Article

\title{
Effect of portulaca olearecea and its interaction with vecuronium on neuromuscular junction in experimental animals
}

\author{
Anjali Tarai $^{1}{ }^{*}$, P. Ansuman Abhisek ${ }^{1}$, S.N. Pandey ${ }^{2}$
}

\begin{abstract}
${ }^{1}$ Department of Pharmacology, SCB Medical College, Cuttack, Odisha, India

${ }^{2}$ Department of Pharmacology, VSS Medical College, Burla, Odisha, India
\end{abstract}

Received: 09 April 2016

Accepted: 07 May 2016

\section{*Correspondence to:}

Dr. Anjali Tarai,

Email: dranjalitarai@gmail.com

Copyright: (C) the author(s), publisher and licensee Medip Academy. This is an openaccess article distributed under the terms of the Creative Commons Attribution NonCommercial License, which permits unrestricted noncommercial use, distribution, and reproduction in any medium, provided the original work is properly cited.

\begin{abstract}
Background: The extracts from the plant Portulaca oleracrea have been mentioned to have muscle relaxant properties in traditional medicine literatures and used as a food supplement. The site of therapeutic action is directly on muscle fibres rather than neuromuscular transmission. The muscle relaxant property is found to be similar with dantrolene in frog rectus abdominis .So objectives of our study to analyze the effect of Portulaca oleracea and its interaction with vecuronium on the neuromuscular junction in experimental animal.

Methods: The study was conducted in two parts i.e. study 1 and study 2 . In study 1:2 $\mathrm{ml}$ and $4 \mathrm{ml}$ Portulaca oleracea fresh aqueous leave juice was given orally to 12 number rabbits and vecuronium 5 microgram $/ \mathrm{ml}$ was given intravenously to all 6 rats through marginal ear vein with the help of scalp vein attached with $10 \mathrm{ml}$ syringe. The head drop time is recorded and reversal of neuromuscular blockade was done with neostigmine $(0.25 \mathrm{mg} / \mathrm{kg})$ along with atropine $(2 \mathrm{mg})$. Study 2: $2 \mathrm{ml}$ and $4 \mathrm{ml}$ of Portulaca oleracea fresh aqueous leave juice was tested on frog's isolated rectus abdominis muscle in Dales's isolated organ bath and its interaction with vecuronium (1 mmole-32 mmole) was recorded.

Results: Portulaca oleracea has muscle relaxant properties, which was recorded which was indicated by decreasing the time of head drop and complete block in study 1 . In study 2 , it also decreased the Ach induced contraction in presence of vecuronium.

Conclusions: The results indicate the muscle relaxant properties fresh juice of Portulac Oleracea probably due to high content of potassium.
\end{abstract}

Keywords: Portulaca oleracea, Vecuronium, Neuromuscular junction, Muscle relaxation

\section{INTRODUCTION}

Neuromuscular blocking drugs promote skeletal muscle relaxation and administered routinely for tracheal intubation during abdominal surgery, orthopaedic manipulation, laryngoscopy, bronchoscopy, oesophagoscopy etc. ${ }^{1}$ Portulaca oleracea (puruni sag in odia) widely grown all around mostly in dry climate and consumed as salad and vegetables. ${ }^{2}$

Portulaca oleracea medicinally used for headache, stomach-ache, painful urination, enteritis, mastitis, lack of milk flow in nursing mother and post-partum bleeding. ${ }^{1,2}$

Externally used to treat burns, earache, insect stings, inflammations, skin sores, ulcers pruritus, eczema and abscesses. ${ }^{3,4}$ Present study was undertaken to know the effect of portulaca oleracea and its interaction with Vecuronium on neuromuscular transmission on animal models.

\section{METHODS}

This study was approved by institutional animal ethics committee, V.S.S. Medical College, Burla, Odisha, India. The Portulaca oleracea plant was freshly collected from local area and was identified and authenticated by the Botany department of Sambalpur University.

\section{Drugs and fluids used}

The following drugs were used in the study - Vecuronium bromide (Neon Laboratories Limited, Mumbai, India), Neostigmine methyl sulphate (Neon Laboratories 
Limited, Mumbai, India). Perfusion fluid used was frog ringer solution for study 2 .

\section{Collection and identification of plant}

Portulaca oleracea was freshly collected from local area from single source during the month of March (as it is grown in ample during January to April) around Hirakud dam on bay of the river Mahanadi were used for the study. Recognition and certification of the leaves of Portulaca oleracea was done by head of the department, department of botany, sambalpur university, Odisha, India. A specimen sample was stored in our department of pharmacology for future reference.

\section{Plant material extraction}

The leaves were cleaned, washed and grounded to paste in pestel and mortar. Then was filtered in whatman filter paper no 40 and fresh juice collected (method of rosenthaller-1930). The prepared juice was used as $2 \mathrm{ml}$ and $4 \mathrm{ml}$ respectively.

\section{Experimental animals}

Eighteen healthy male albino rabbits weighing $2.5 \mathrm{~kg}$ to $3.5 \mathrm{~kg}$ bred in the animal house of the department of pharmacology, VSS Medical College, Burla, Odisha, India were used. They were kept under standard laboratory conditions with a 12 hours daylight cycle and had free access to feed and water and were acclimatized for three weeks to laboratory conditions before the commencement of the experiments.

\section{Statistics}

One way anova was used.

Two types of study were done as per the designed study protocol (Table 1).

\section{Study 1}

For this study eighteen healthy male albino rabbits weighing $2.5 \mathrm{~kg}$ to $3.5 \mathrm{~kg}$ were randomly selected from departmental animal house divided into three groups, having six in each. Group I was given, Vecuronium (5 $\mu \mathrm{g} / \mathrm{ml}$ ) diluted with $10 \mathrm{ml}$ of normal saline in a $10 \mathrm{ml}$ syringe, given slow intravenously through marginal ear vein of rabbit with the help of a scalp vein, which served as negative control. Group II and III were given Portulaca oleracea, $2 \mathrm{ml}$ and $4 \mathrm{ml}$ per orally and Vecuronium $(5 \mu \mathrm{g} / \mathrm{ml})$ diluted with $10 \mathrm{ml}$ of normal saline in a $10 \mathrm{ml}$ syringe, given slow intravenously through marginal ear vein with the help of a scalp vein respectively after 30 minutes of Portulaca oleracea, which served as tests.

Table 1: Protocol design-different drugs administered with their route and dose.

\begin{tabular}{|llll|}
\hline & Drugs & Route & Type \\
\hline Group I & $\begin{array}{l}\text { Vecuronium } \\
(5 \mu \mathrm{g} / \mathrm{ml})\end{array}$ & Intavenous & Control \\
\hline Group II & $\begin{array}{l}\text { Portulaca } 2 \\
\mathrm{ml}+\mathrm{Vec} \\
(5 \mu \mathrm{g} / \mathrm{ml})\end{array}$ & $\begin{array}{l}\text { Per } \\
\text { Oral+Intravenous }\end{array}$ & Test \\
\hline \multirow{2}{*}{ Group III } & $\begin{array}{l}\text { Portulaca } 4 \\
\mathrm{ml}+\mathrm{Vec} \\
(5 \mu \mathrm{g} / \mathrm{ml})\end{array}$ & $\begin{array}{l}\text { Per } \\
\text { Oral+Intravenous }\end{array}$ & Test \\
\hline
\end{tabular}

All the doses were selected as per literature. ${ }^{5,6}$ Vecuronium was freshly prepared before administration. Time of head drop and complete block was recorded. Data was analysed by one way ANOVA mentioned in (Table 2).

Table 2: Time of onset of head drop and complete block in minutes.

\begin{tabular}{|c|c|c|c|}
\hline Group & $\begin{array}{l}\text { Time } \\
\text { (in M }\end{array}$ & $\begin{array}{l}\text { onset of head drop } \\
\text { tes) (Mean } \pm \text { SD) }\end{array}$ & $\begin{array}{l}\text { Time for complete block } \\
\text { (in Minutes) (Mean } \pm \text { SD) }\end{array}$ \\
\hline 1 & Vecuronium $5 \mathrm{mcg} / \mathrm{ml}$ i.v. & $9.36 \pm 1.2$ & $15.8 \pm 0.2$ \\
\hline 2 & Per oral $2 \mathrm{ml}+\mathrm{Vec} 5 \mathrm{mcg} / \mathrm{ml}$ i.v. & $6.25 \pm 2.3 * * *$ & $10.5 \pm 0.5 * * *$ \\
\hline 3 & Per oral $4 \mathrm{ml}+\mathrm{Vec} 5 \mathrm{mcg} / \mathrm{ml}$ i.v. & $5.36 \pm 1.6^{* * *}$ & $10.2 \pm 0.3 * * *$ \\
\hline
\end{tabular}

One way ANOVA F (df); $11.13(2,15) ; 10.27(2,15)$ p $<0.01<0.01$

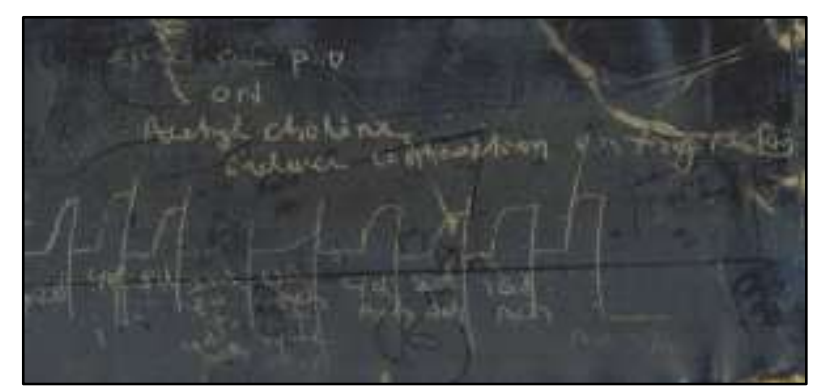

Figure 1: Effect of portulaca oleracea on acetylcholine induced muscle contraction.

\section{Rabbit head drop method}

The procedure of rabbit head drop was followed as described by Verny. ${ }^{7}$

\section{Study 2}

Isolated frog rectus abdominis muscle was mounted in Dale's isolated organ bath. Graded dose response of acetylcholine was recorded and submaximal dose (SMD) of acetylecholine was determined. Then fresh juice of Portulaca oleracea was added into the organ bath in graded doses. Then the tissue was left for thirty minutes was given for the action of portulaca oleracea, 
submaximal dose (SMD) of acetylcholine was added into the bath and response was recorded.

\section{RESULTS}

Time for onset of head drop for different groups and time for complete block was recorded (in minutes) and was expressed in (Table 2).

\section{Study 2}

In isolated frog rectus abdominis muscle preparation, $2 \mathrm{ml}$ and $4 \mathrm{ml}$ of portulaca oleracea leaf juice was tested. It showed, reduced skeletal muscle contraction in dose dependant manner in presence of vecuronium and the effect was found reversed after 1 hour (Figure 1).

\section{DISCUSSION}

In study 1 it was found that Portulaca oleracea showed muscle relaxant properties by increasing the time of head drop and complete block. After putting one way ANOVA, the result was found to be very highly significant. In study 2, it also decreased the contraction induced by acetylcholine in presence of vecuronium. The probable mechanism may be due to high concentration of potassium ion in the juice. ${ }^{6,8}$ It also rich in omega 3 fatty acid, noradrenaline, vitamin A, B, C, niacin, nicotinamide, a tocopherol, bcarotin, minerals, fattyacid, glutathione, glutamic acid and aspartic acid. ${ }^{9-12}$ Our observations on potentiation of neuromuscular relaxation with Portulaca oleracea is in accordance with previous studies. $^{12}$

Though muscle relaxant property of Portulaca oleracea probably largely depends on the level of potassium which could not be found out due to the unavailability of high performance thin liquid chromatography (HPTLC) which is the limitation of the study, but the study regarding muscle relaxant activity of Portulaca oleracea is very sparse. Further studies should be in line to find out whether the increased extracts potassium could have either augmented the phytoconstituents muscle relaxant activity and whether direct juice or aqueus extract or ethanolic extract is far more effective.

\section{CONCLUSION}

Portulaca Oleracea has muscle relaxant properties that of the vecuronium. To know the actual mechanism of action further study may be under taken. Its possible use in different conditions can be for reducing the adverse effects of vecuronium.

Funding: No funding sources

Conflict of interest: None declared

Ethical approval: The study was approved by the Institutional Ethics Committee

\section{REFERENCES}

1. Patel TK, Patel PB, Tripathi CB. Effect of pantoprazole and its interactions with vecuronium on the neuromuscular junction. IJP. 2010;42(1):36-9.

2. Englehar T, Webster NR. Pulmonary aspiration of gastric contents in anaesthesia. $\mathrm{Br} \mathrm{J}$ Anaesthesia. 1999;83:453-60.

3. Albert CC, Baker JO, COOK JE. A rational approch to preanaesthetic medication drugs. 1989;37:219-28.

4. Okamoto TAC, Fukushimak T. Neuromuscular blocking effect of ORG9428 A new non depolarising muscle relaxtant and its recovery with various antagonist in vitro muscle.1992;41:1467-73.

5. Olssson GL, Hallen B, HambralchJonzon $\mathrm{K}$. Aspiration during anaesthesia. A computer aided study of 185-358 anaesthetics. Altaanaesthesiolscaned. 1986;30:84-92.

6. Habtemariam S, Harvey AL, Waterman PG. The muscle relaxtant properties of portulacaoleracea are associated with high concentration of potassium ions J Ethnopharmacol. 1993;40(3):195-200.

7. Varney RE, Linegar LR, Hoalday HA. The assay of curare by rabbit head drop method. J Pharmacol Exp Ther. 1949;97:72-83.

8. Lix Howe P. Zhou YF, XU ZH, HocartC, Zhang R. Fatty acids and b-carotene in Australian purslane portulacaoleracea varieties. J Chomatogi. 2000;893:207-13.

9. Barbosa Filho JM, Alencar AA, Nunes XP, Tomaz AC, SenaFilho JG, Athhhayde Fiho PF, et al. Sources of alpha, beta, gamma, delta and epsilon-carotenes. Atweentieth century review Rev Bras Famacogn. 2008;18:135-54.

10. Chatterjee A, Chandra S, Pakrashi. The treatise on Indian medicinal plants. Pubimform Directorate. 1956;1243-4.

11. Smopoulous AP, Noman HA, Gillaspy, Duke JA. Common purslane. A source of omega -3 fatty acids and anti-oxidants. J Am Coll Nur. 1992;11:374-82.

12. Party O, Marks JA, Okwuasab FK. The skeletal muscle relaxant action of portulacaoleracea. Role of potassium ions. J Ethinopharmacol. 1993;49:187-94.

Cite this article as: Tarai A, Abhisek PA, Pandey SN. Effect of portulaca olearecea and its interaction with vecuronium on neuromuscular junction in experimental animals. Int J Basic Clin Pharmacol 2016;5:1087-9. 